Egyptian Journal of Aquatic Biology \& Fisheries

Zoology Department, Faculty of Science,

Ain Shams University, Cairo, Egypt.

ISSN $1110-6131$

Vol. (3): 451 - 462 (2020)

www.ejabf.journals.ekb.eg

\title{
Biodiesel Production, Characterization and Biochemical Variability by Microalga Nannochloropsis oculata under Stressed Culture Conditions
}

\author{
Hanan M. Khairy ${ }^{*}$, Hawazin H. Mutawie ${ }^{2}$, Heba S. El-Sayed ${ }^{3}$, Nayrah A. Shaltout ${ }^{4}$ \\ ${ }^{1}$ Hydrobiology Laboratory, Marine Environmental Division, National Institute of Oceanography \\ and Fisheries Kayet Bay, Alexandria, Egypt. \\ ${ }^{2}$ Phycology Department of Biology, Faculty of Applied Sciences, Umm Al-Qura University, \\ Saudi Arabia. \\ ${ }^{3}$ Fish Reproduction, Larval Rearing Laboratory (Marine Hatchery), National Institute of \\ Oceanography and Fisheries, Kayet Bay, Alexandria, Egypt. \\ ${ }^{4}$ Marine Chemistry Laboratory, National Institute of Oceanography and Fisheries, Alexandria, \\ *Corresponding Author: hanan_khairy@yahoo.com
}

\section{ARTICLE INFO}

\section{Article History:}

Received: April 12, 2020

Accepted: May 28, 2020

Online: June 1, 2020

Keywords:

Salt stress,

Nitrogen,

Phosphorus,

Starvation,

Biodiesel,

Nannochloropsis oculata
Microalgae are recognized as a promising source for biofuel production, which is known as a renewable source of energy. This study was conducted to optimize the biodiesel production quantitatively and qualitatively by the microalga, Nannochloropsis oculata upon culturing on two different culture media (F/2 and Boussiba media) as a comparative study through stress in the main culture compositions by 1) Treating with different salinity concentrations (20, 40 and $60 \mathrm{psu})$, 2) Depleting from phosphorus (P) and nitrogen (N) sources for the two media. After different treatments, the growth rate, protein, carbohydrate, lipid, and fatty acids contents were determined. The algal analysis cleared that increasing salinity to $60 \mathrm{psu}$ in $\mathrm{F} / 2$ medium and $40 \mathrm{psu}$ on the Boussiba medium led to increasing the number of $N$. oculata cells with the maximum protein and carbohydrate contents at late exponential phase. At lower salinity, there were no significant differences in total protein content while carbohydrate contents showed slight variations, and its minimum values were obtained at (N) starved medium. Total lipid and total fatty acids content were higher in $N$. oculata cultured on F/2 medium than on Boussiba medium at different treatments and achieved its maximum when cultured on N-starved > P-depleted > Salt-stressed 60psu, respectively. The highest physical properties of the produced biodiesel represented in the degree of unsaturation (SD), iodine values (IV), Cetane number (CN), and oxidation stability were recorded in $N$. oculata cultured on higher salinities and Ndepleted conditions in the two media. Using higher salinities up to 40psu (available in the natural seawater), N-depletion or P-depletion in F/2 medium for achieving highly economical results in the production of $N$. oculata microalga. Biodiesel produced from $N$. oculata oil can be considered as a potential candidate for commercial sources.

\section{INTRODUCTION}

Biofuels are considered promising alternative energy source that could contribute to fuel supplies in the form of biodiesel (Chisti, 2007). Biofuels, generated from biomass, are promising sources of fossil-derived fuels due to their distinct advantages such as carbon 
neutrality, reduced emissions of gaseous pollutants, continuous availability of biomass feedstocks, and their safety of production by farming (Li et al., 2011; Saifuddin and Boyce, 2016). Having such these sources can be an interesting of reducing greenhouse gases (Mata et al., 2010). Some studies have been conducted to test the capability of different microorganisms as a source of biofuel to replace the conventional fuel (Prince and Kheshgi, 2005). Microalgae particularly are rich in oil with rapid growth rates which make them an effective candidate for biofuel production (Chisti, 2007).

Although there are numerous advantages to microalgal biodiesel production, the technology and our knowledge are limited. The energy efficiency of microalgae will also reduce the amount of fertilizer and nutrients needed, thus reducing pollution (Schenk $\boldsymbol{e t}$ al., 2008). Under nutrient stress, cells favor to accumulate lipid particularly triacyl glycerol (TAG) as the dominant ingredient (Sibi et al., 2016), and depletion of $\mathrm{N}$ and $\mathrm{P}$ direct fixing carbon to lipids or carbohydrates synthesis. Therefore, $\mathrm{N}$ and $\mathrm{P}$ starvation is important for lipids metabolism (Kamalanathan et al., 2016).

The utilization of saline water in non-arable areas will open up economic opportunities to arid areas. In general, the production of lipids is inversely related to the algae growth because algae tend to produce more oil when they are under stressful conditions. Salinity showed considerable effect on protein produced by microalgae (Moisander et al., 2002). Several factors influences the lipid content of microalgae, such as phosphate limitation (Reitan et al., 1994), salinity (Rao et al., 2007; El-Sheekh et al. 2013, 2017, 2019), and iron content of the medium also affect the algal growth (Liu $\boldsymbol{e t}$ al., 2008) Johansen et al. (1990) reported that all except one strain of Chaetoceros muelleri studied exhibited increases in lipid content under nutrient stress and that in most cases nitrogen stress, in particular, led to a higher lipid content.

Kilham et al. (1997) found that $\mathrm{P}$ and N-limitation reduced protein composition and increased lipid composition in Ankistrodesmus facatus. Reitan et al. (1994) cultured the microalgae Phaeodactylum tricornutum, Chaetoceros sp., Isochrysis galbana, Nannochloropsis atomus, Tetraselmis sp. and Gymnodinum sp., they reported the increase of lipid contents at different nitrogen-starved media. When sufficient nutrients are available, proteins are synthesized; however, when nutrients are limited, cell division is suppressed and a greater amount of carbon is available for lipid storage (Sukenik and Wahnon, 1991). The current study aimed to optimize the culture conditions mainly salinity and essential nutrients starvation ( $\mathrm{N}$ and $\mathrm{P}$ ) for biodiesel production by Nannochloropsis oculata through a comparative study for two commonly used culture media (F/2 and Boussiba media) with commercial ingredients constitution. Since the two media consituents are quantitatively different, Boussiba medium contain extremely higher and costly than F2 medium.

\section{MATERIALS AND METHODS}

\section{Organism and growth conditions}

The culture of marine microalga Nannochloropsis oculata was kindly provided from the culture collection maintained in the algal unit presented in the marine hatchery, National Institute of Oceanography and Fisheries (NIOF), Alexandria, Egypt. The microalga was cultured on two different culture media named F/2 and Boussiba medium (Guillard, 1975; Boussiba et al., 1987) at different salinities (20, 40 and 60 psu) and without nitrogen and phosphorus. The cultures were grown in $1000 \mathrm{ml}$ Erlenmeyer flasks 
with $500 \mathrm{~mL}$ medium. The cultures were performed in a temperature-controlled incubator at $25{ }^{\circ} \mathrm{C}$ providing $24 \mathrm{~h}$ fluorescent illumination (40-watt, white tube light). To avoid sticking, the cultures were shaken 2-3 times every day. All the glassware and media were sterilized prior to inoculation and culture.

\section{Growth measurements and biochemical analysis of $N$. oculata}

A direct microscopic count of $N$. oculata was performed by hemocytometer, and the mean number of cells/ml was obtained. Cell numbers were applied triplicate every 2 days.

Total protein content was determined by the Folin-phenol method (Lowry et al., 1951). Total carbohydrate content was determined according to the phenol-sulfuric acid method using glucose as standards (Dubois et al., 1956). Total lipid was analyzed gravimetrically after extraction with chloroform-methanol (2:1) using the modified Folch method (Bligh and Dyer, 1959). Fatty acid methyl esters (FAMEs) were prepared (Vogel, 1975), and the analysis was performed in a gas liquid chromatograph (Pye Unicam Series 304 Gas Chromatograph) equipped with dual flame ionization detector and dual channel recorder. FAMEs were identified by comparing the retention times of experimental samples to those of known standards.

\section{Evaluation of biodiesel properties}

The Average Degree of Unsaturation (ADU\%), Iodine Value (IV, $\mathrm{g} \mathrm{I}_{2} .100 \mathrm{~g}^{-1}$ oil), Cetane Number (CN), Kinematic viscosity (vi, $\left.\mathrm{mm}^{2} \mathrm{~s}^{-1}\right)$, density $(\rho)$, Higher Heating Value (HHV), Saponification Value (SV, $\mathrm{mg} \mathrm{KOH} \mathrm{g}^{-1}$ ), Long Chain Saturation Factor (LCSF, wt\%) and Cold Filter Plugging Point (CFPP, C) and kinematic viscosity (vi, mm $2 \mathrm{~s}-1$ ) were calculated as described in Ashour et al. (2019); Ramirez-Verduzco et al. (2012) and Mitra et al. (2016) in the $N$. oculata cultured on F/2 and Boussiba media treated with different concentrations of salts, phosphorous $(\mathrm{P})$ and nitrogen $(\mathrm{N})$ depletion as shown in equations from 1 to 6 :

$\mathrm{DU}=\Sigma[\mathrm{MUFA}+(2 \times \mathrm{PUFA})]$ (Pan et al., 2017)

Where, MUFA: monounsaturated and PUFA: polyunsaturated fatty acids percentages.

$$
\begin{aligned}
& \mathrm{SV}=\Sigma[(560 \times \mathrm{N} \%) / \mathrm{M}] \quad(\text { Zhu } \text { et al., 2017) } \\
& \mathrm{IV}=\Sigma[(254 \times \mathrm{N} \% \times \mathrm{D}) / \mathrm{M}] \quad(\text { Rawat } \text { et al., 2011) } \\
& \mathrm{CN}=46.3+(5458 / \mathrm{SV})-(0.225 \times \mathrm{IV})(\text { Nguyen } \text { et al., 2016) }
\end{aligned}
$$

where, N\%: the percentage of each fatty acid; M: the molecular mass of the fatty acid; and $\mathrm{D}$ : the number of carbon-carbon double bonds.

$$
\mathrm{LCSF}=(0.1 \times \mathrm{C} 16: 0)+(0.5 \times \mathrm{C} 18: 0)+(1 \times \mathrm{C} 20: 0)+(1.5 \times \mathrm{C} 22: 0)+(2 \times \mathrm{C} 24: 0)
$$

(Abomohra et al., 2018).

$$
\mathrm{CFPP}=(3.1417 \times \mathrm{LCSF})-16.477 \quad \text { (Shao et al., 2018) }
$$

Where, C16:0, C18:0, C20:0, C22:0 and C24:0 represent the weight percentage of the corresponding fatty acids.

\section{Statistical analysis}

Each measurement was done in triplicates and the mean and SD of the experimental results was calculated using MS-Excel. Two-way ANOVA was used to test the effects of salinities, $\mathrm{N}$ and $\mathrm{P}$ depletion on the growth, protein, carbohydrate, lipid and fatty acids. When differences were found in the two-way ANOVA, Tukey's multiple comparison test (HSD) of one-way ANOVA was used to compare the mean differences (Zar, 1984) by the SPSS statistical package (Version 12.0, SPSS, Chicago, IL). Differences were considered significant at $p \leq 0.05$. 


\section{RESULTS}

\section{Effect of salinity on Nannachloropsis oculata growth post 8 days of culture}

The growth represented as cell number of $N$. oculata on $\mathrm{F} / 2$ media was greatest (doubling) than Boussiba media (Figure 1 and 2, respectively) at different salinities, $\mathrm{N}$ and $\mathrm{P}$ starved. The results showed that $N$. oculata cultured on $\mathrm{F} / 2$ medium gives the maximum cell number at salinity 60psu (Figure 1), ANOVA test confirms that cell numbers of $N$. oculata cultured on $\mathrm{F} / 2$ medium was significantly different at the various treatments $(p \leq 0.05)$.

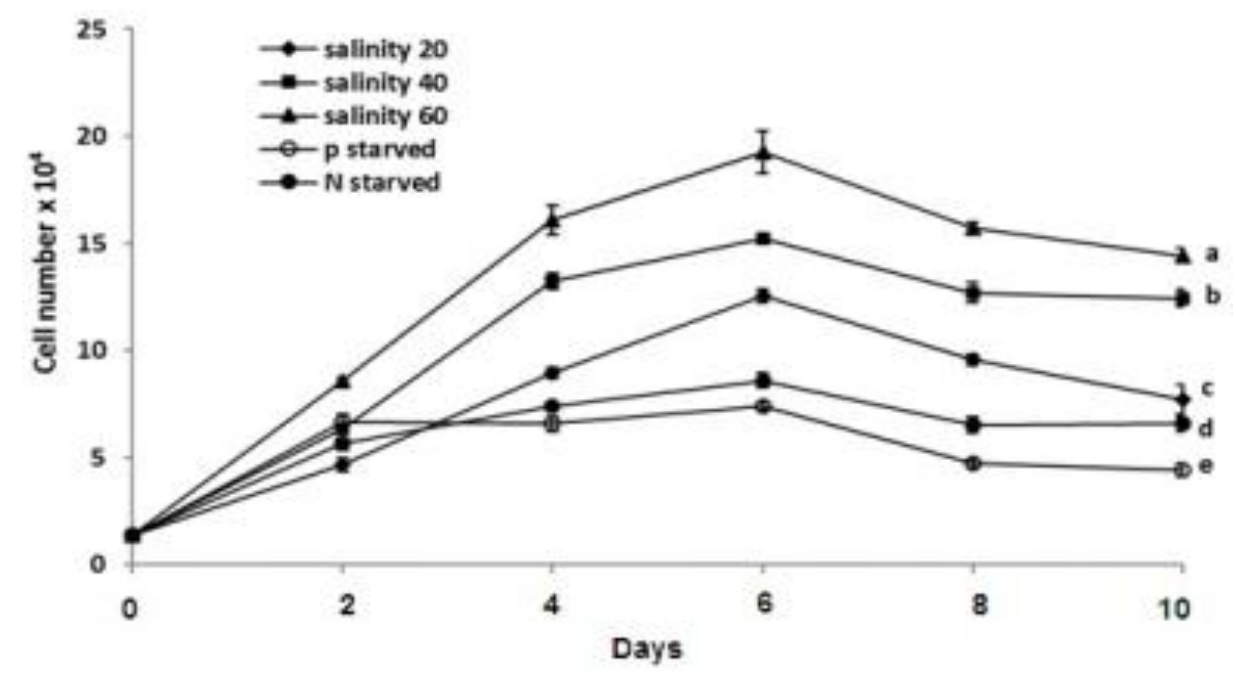

Fig. 1. Impact of different salinity concentrations, $\mathrm{P}$ and $\mathrm{N}$ starvation on the cell number of $N$. oculata cultured on $\mathrm{F} / 2$ medium.

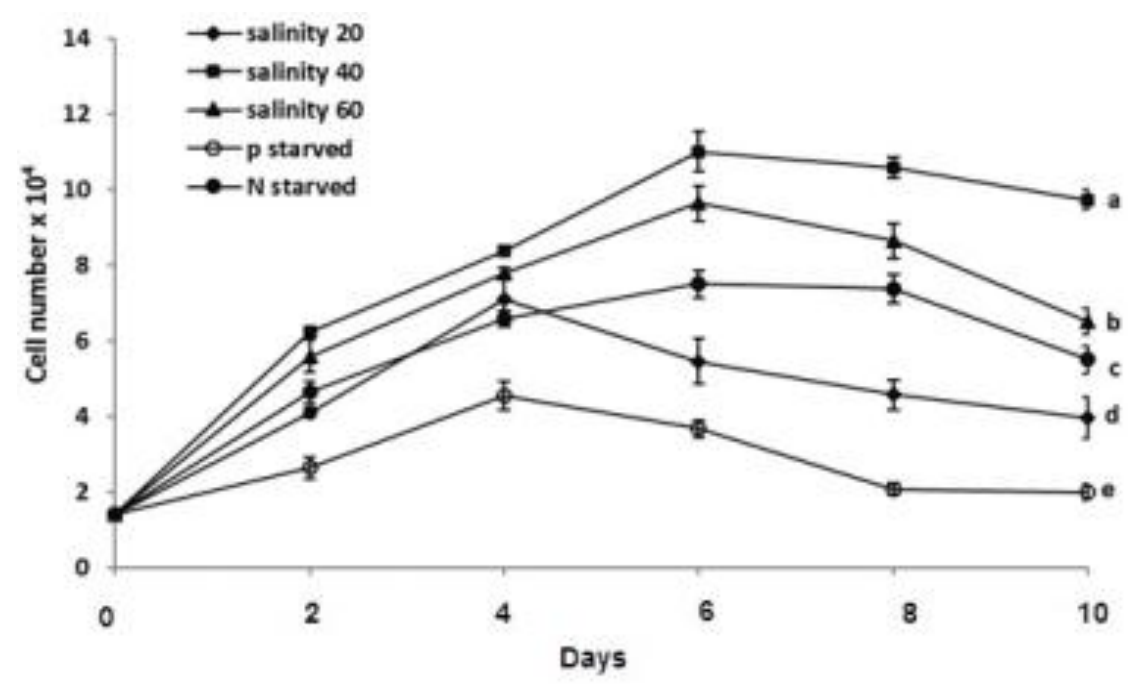

Fig. 2. Impact of different salinity concentrations, $\mathrm{P}$ and $\mathrm{N}$ starvation on the cell number of N. oculata cultured on Boussiba medium during the culture period. 
2. Effect of salinity on total protein and carbohydrate contents of Nannachloropsis oculata post 8 days of culture

As shown in Figure 3, there were no significant differences in total protein content in $N$. oculata grown on the two-culture media (F/2 and Boussiba) at different salinity concentrations. Carbohydrate content showed slight variations when $N$. oculata cultured on F/2 and Boussiba media and attained its maximum at salinity 60psu, its minimum was at $(\mathrm{N})$ starved medium (Figure 4).

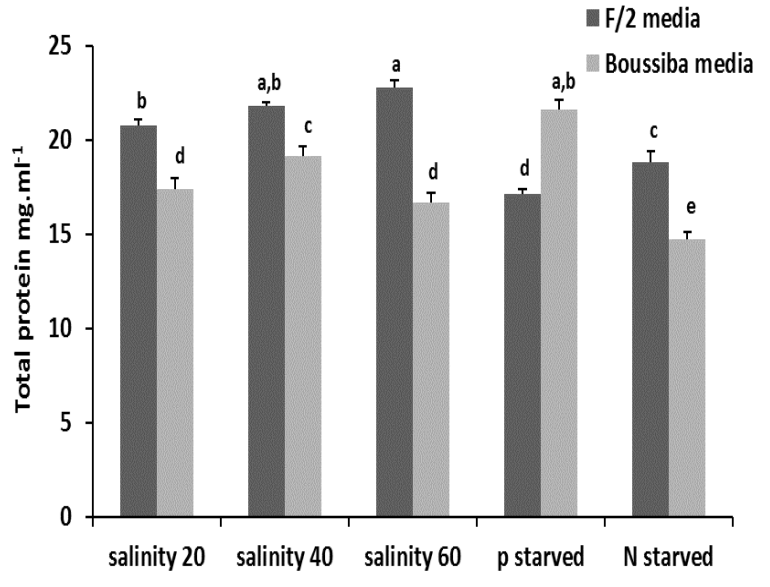

Fig. 3. Total protein content of $N$. oculata cultured on $\mathrm{F} / 2$ and Boussiba media.

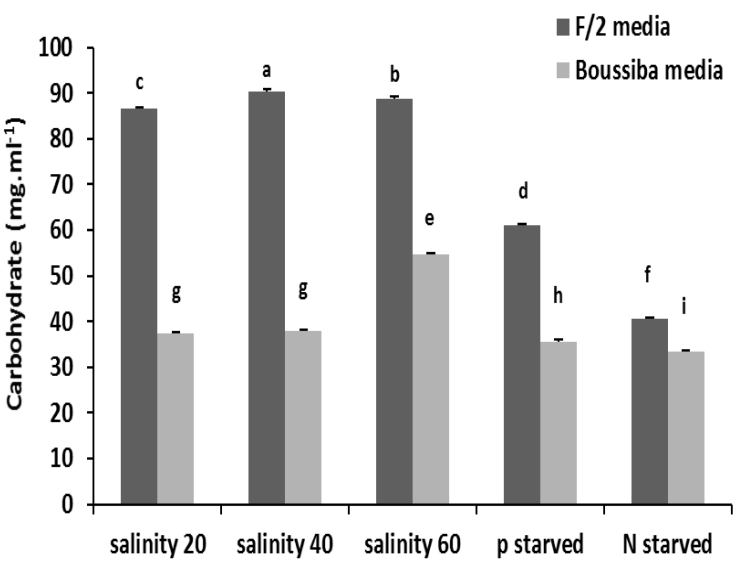

Fig. 4. Total carbohydrate content of N. oculata cultured on $\mathrm{F} / 2$ and Boussiba media.

\section{Effect of salinity on total lipid and fatty acids content of Nannachloropsis oculata post 8 days of culture}

The total lipid content was higher in $N$. oculata cultured on $\mathrm{F} / 2$ medium than on Boussiba medium at different treatments (Figure 5) and attained its maximum when cultured on $\mathrm{N}$-starved $\mathrm{F} / 2$ medium. The total fatty acids were increased upon culturing $N$. oculata on F/2 media treated with $60 \mathrm{psu}(518 \mu \mathrm{g} / \mathrm{L})$. Starvation of (P) from F/2 led to an increase in the total fatty acid contents $(656.71 \mu \mathrm{g} / \mathrm{L})$, when compared with all different treatments.

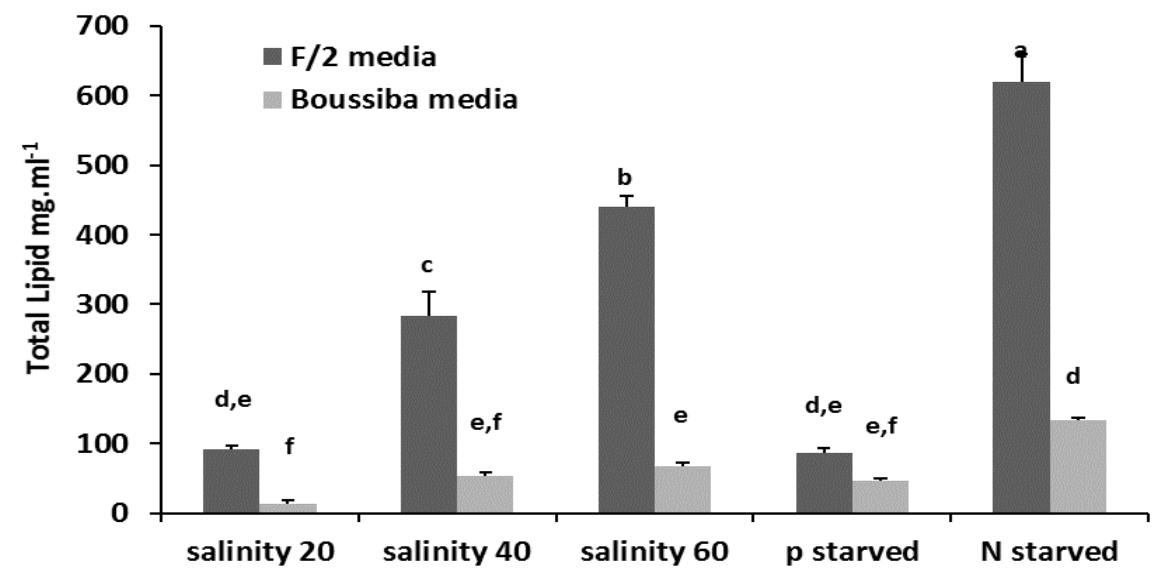

Fig. 5. Total lipid content of $N$. oculata cultured on F/2 and Boussiba media. 
Table 1. Fatty acids analysis of Nannochloropsis oculata cultured on F/2 medium treated with different concentrations of salinities, $\mathrm{P}$ and $\mathrm{N}$ starvation.

\begin{tabular}{|c|c|c|c|c|c|c|c|c|c|c|}
\hline \multirow[b]{2}{*}{$\begin{array}{c}\text { Fatty } \\
\text { acid }\end{array}$} & \multicolumn{5}{|c|}{ Treatment $\mathrm{F} / 2$ medium } & \multicolumn{5}{|c|}{ Treatment Boussiba medium } \\
\hline & $\begin{array}{l}\text { Salin. } \\
\text { 20psu }\end{array}$ & $\begin{array}{l}\text { Salin. } \\
\text { 40psu }\end{array}$ & $\begin{array}{l}\text { Salin. } \\
\text { 60psu }\end{array}$ & $\begin{array}{c}p \\
\text { starved }\end{array}$ & $\begin{array}{c}\mathbf{N} \\
\text { starved }\end{array}$ & $\begin{array}{l}\text { Salin. } \\
\text { 20psu }\end{array}$ & $\begin{array}{l}\text { Salin. } \\
\text { 40psu }\end{array}$ & $\begin{array}{l}\text { Salin. } \\
\text { 60psu }\end{array}$ & $\begin{array}{c}\mathbf{p} \\
\text { starved }\end{array}$ & $\begin{array}{c}\mathrm{N} \\
\text { starved }\end{array}$ \\
\hline \multicolumn{11}{|c|}{ Saturates (SFA) } \\
\hline C 6:0 & 0.4 & 0 & 3.82 & 0 & 0 & 0 & 0 & 0 & 0.21 & 0.18 \\
\hline C 8:0 & 1.22 & 0.8 & 27.59 & 0.17 & 4.4 & 0 & 0 & 0 & 0.11 & 0.39 \\
\hline C 10:0 & 0.97 & 0.85 & 1.62 & 0 & 1.46 & 0 & 0 & 0 & 0.13 & 0 \\
\hline C 11:0 & 1.81 & 0 & 1.44 & 0 & 1.58 & 0 & 0.59 & 0.25 & 2.17 & 1.29 \\
\hline C 12:0 & 9.8 & 1 & 2.3 & 0.46 & 1.35 & 0.17 & 0.67 & 0.37 & 1.03 & 0.33 \\
\hline C 13:0 & 4.54 & 5.09 & 1.95 & 3.28 & 4.47 & 0.53 & 6.39 & 0.94 & 1.13 & 3.13 \\
\hline C 14:0 & 13.07 & 16.98 & 13.29 & 35.83 & 1.85 & 0.43 & 10.29 & 5.17 & 7.86 & 25.58 \\
\hline C 15:0 & 1.5 & 1.72 & 0.69 & 2.01 & 1.43 & 0.42 & 2 & 0.59 & 0.56 & 1.45 \\
\hline C 16:0 & 50.23 & 44.51 & 47.66 & 333.14 & 363.96 & 2.39 & 19.65 & 15.39 & 70.41 & 168.57 \\
\hline C $10: 0$ & $(14.20 \%)$ & $(33.65 \%)$ & $(9.19 \%)$ & $(50.73 \%)$ & $(44.93 \%)$ & $(22.87 \%)$ & $(29.77 \%)$ & $(36.66 \%)$ & $(47.08 \%)$ & $(37.39 \%)$ \\
\hline C 17:0 & 0.62 & 0.79 & 1.38 & 0.6 & 1.42 & 0 & 0 & 0 & 0.23 & 0.84 \\
\hline C 18:0 & 24.69 & 6.44 & 23.12 & 7.02 & 19.28 & 0.55 & 1.87 & 2.69 & 1.35 & 17.83 \\
\hline C 20:0 & 6.76 & 1.93 & 8.83 & 0 & 1.3 & 0 & 0 & 0 & 0 & 1.1 \\
\hline C 21:0 & 37.95 & 11.46 & 6.92 & 0 & 1.85 & 0.2 & 1.05 & 1.73 & 0 & 1.48 \\
\hline C 22:0 & & & & & & 0 & 0 & 0 & 0 & 0.93 \\
\hline C 23:0 & 2.92 & 0 & 0 & 0 & 0 & 0 & 1.85 & 2.07 & 0 & 0 \\
\hline Sum & 156.48 & 91.57 & 140.61 & 382.51 & 404.35 & 4.69 & 44.36 & 29.2 & 85.19 & 223.1 \\
\hline $\begin{array}{c}\% \text { to } \\
\text { total } \\
\text { FA }\end{array}$ & $44.22 \%$ & $69.23 \%$ & $27.12 \%$ & $58.25 \%$ & $49.92 \%$ & $44.88 \%$ & $67.21 \%$ & $69.56 \%$ & $56.96 \%$ & $49.49 \%$ \\
\hline \multicolumn{11}{|c|}{ Monounsaturates (MUFA) } \\
\hline C 14:1 & 1.68 & 1.91 & 0.98 & 1.31 & 2.32 & 0.46 & 2.64 & 0.81 & 0.59 & 1.46 \\
\hline C 15:1 & 1.54 & 1.65 & 1.41 & 1.06 & 1.27 & 0.25 & 0.81 & 0.51 & 0.39 & 1.04 \\
\hline C 16:1 & $\begin{array}{c}5.51 \\
(1.56 \%)\end{array}$ & $\begin{array}{c}9.26 \\
(7.00 \%)\end{array}$ & $\begin{array}{c}18.04 \\
(3.48 \%)\end{array}$ & $\begin{array}{c}161.31 \\
(24.56 \%)\end{array}$ & $\begin{array}{c}220.27 \\
(27.19 \%)\end{array}$ & $\begin{array}{c}0.2 \\
(1.91 \%)\end{array}$ & $\begin{array}{c}1.54 \\
(2.33 \%)\end{array}$ & $\begin{array}{c}0.17 \\
(0.40 \%)\end{array}$ & $\begin{array}{c}21.2 \\
(14.17 \%)\end{array}$ & $\begin{array}{c}94.72 \\
(21.01 \%)\end{array}$ \\
\hline C 17:1 & 2.57 & 5.12 & 2.62 & 0.6 & 2.44 & 0.34 & 1.21 & 1.12 & 0.31 & 1.8 \\
\hline C 18:1 & 26.79 & 2.54 & 0 & 0 & 0 & 0 & 1.22 & 0 & 0 & 0 \\
\hline C 20:1 & 2.51 & 2.49 & 26.88 & 0 & 0 & 0 & 0 & 2.14 & 2.22 & 4.77 \\
\hline C 22:1 & 5.83 & 0 & 7.61 & 0 & 4.94 & 0.71 & 1.16 & 3.87 & 1.04 & 3.16 \\
\hline Sum & 46.43 & 22.97 & 57.54 & 164.28 & 231.24 & 1.96 & 8.58 & 8.62 & 25.75 & 106.95 \\
\hline $\begin{array}{c}\% \text { to } \\
\text { total } \\
\text { FA }\end{array}$ & $13.12 \%$ & $17.37 \%$ & $11.10 \%$ & $25.02 \%$ & $28.55 \%$ & $18.76 \%$ & $13.00 \%$ & $20.53 \%$ & $17.22 \%$ & $23.72 \%$ \\
\hline \multicolumn{11}{|c|}{ Polyunsaturates (PUFA) } \\
\hline C 18:2 & $\begin{array}{c}116.33 \\
(32.88 \%)\end{array}$ & $\begin{array}{c}2.91 \\
(2.20 \%)\end{array}$ & $\begin{array}{c}149.29 \\
(28.80 \% \\
)\end{array}$ & $\begin{array}{c}74.65 \\
(11.37 \%)\end{array}$ & $\begin{array}{c}166.7 \\
(20.58 \%)\end{array}$ & 0.0 & 0.48 & 0 & 7.39 & 83.28 \\
\hline C 18:3 & 15.33 & 1.19 & 1.42 & 0.68 & 0 & 0.43 & 0 & 0.23 & 0.25 & 1.18 \\
\hline C 20:2 & 1.06 & 0.35 & 47.92 & 0 & 5.63 & 0 & 0 & 0 & 1.19 & 0 \\
\hline C 20:3 & 0 & 0 & 22.31 & 0 & 0 & 0.24 & 0.56 & 0 & 0 & 1.89 \\
\hline C 20:4 & 1.28 & 1 & 44.07 & 11.33 & 2.12 & 0 & 0 & 0 & 0.81 & 4.47 \\
\hline C 20:5 & 0 & 0 & 31.55 & 3.16 & 0 & 0 & 0 & 0 & 0.37 & 2.28 \\
\hline C 22:2 & 4.26 & 0 & 0 & 0 & 0 & & & & & \\
\hline C 22:6 & 12.66 & 12.27 & 23.7 & 20.1 & 0 & $\begin{array}{c}3.13 \\
(29.95 \%) \\
\end{array}$ & $\begin{array}{c}12.02 \\
(18.21 \%) \\
\end{array}$ & $\begin{array}{c}3.93 \\
(9.36 \%) \\
\end{array}$ & $\begin{array}{c}28.61 \\
(19.13 \%) \\
\end{array}$ & $\begin{array}{r}27.69 \\
(6.14 \%) \\
\end{array}$ \\
\hline Sum & 150.92 & 17.72 & 320.26 & 109.92 & 174.45 & 3.8 & 13.06 & 4.16 & 38.62 & 120.79 \\
\hline $\begin{array}{c}\% \text { to } \\
\text { total } \\
\text { FA }\end{array}$ & $42.65 \%$ & $13.40 \%$ & $61.78 \%$ & $16.74 \%$ & $21.54 \%$ & $36.36 \%$ & $19.79 \%$ & $9.91 \%$ & $25.82 \%$ & $26.79 \%$ \\
\hline $\begin{array}{l}\text { Total } \\
\text { fatty } \\
\text { acids } \\
\text { (ug/l) }\end{array}$ & 353.83 & 132.26 & 518.41 & 656.71 & 810.04 & 10.45 & 66 & 41.98 & 149.56 & 450.84 \\
\hline
\end{tabular}


The dominant fatty acid was $\mathrm{C} 16: 0$ which resulted in high saturated fatty acid content of $58.25 \%$ of total fatty acids (Table 1). However, polyunsaturated fatty acids represented $16.74 \%$ of total fatty acids. Upon culturing cells on F/2 media starved from $(\mathrm{N})$, the total fatty acids recorded the highest concentrations among all treatments $(810.04$ $\mu \mathrm{g} / \mathrm{L})$. While, the use of Boussiba as a culturing media for $N$. oculate, the total fatty acids were increased in the 60psu salinity $(66 \mu \mathrm{g} / \mathrm{L})$. Starvation of $N$ in this media led to increase in the total fatty acids up to $450 \mu \mathrm{g} / \mathrm{L}$ and P depletion $(149.56 \mu \mathrm{g} / \mathrm{L})$ (Table 1).

\section{Biodiesel properties of Nannachloropsis oculata cultured on F/2 and Boussiba media treated with different salinity, $P$ and $N$ starvation}

As shown in Table 3, the results showed that the average degree of unsaturation and iodine values were the highest value in $N$. oculata cultured on F/2 medium at salinity $60 \mathrm{psu}$ and on Boussiba medium at salinity 40psu. The long chain saturation factor (LCSF) was in the range 6 on Boussiba medium at salinity 60psu and $\mathrm{N}$ starved condition. The best cetane number $(\mathrm{CN})$ was obtained upon culturing $N$. oculata on $\mathrm{F} / 2$ medium at salinity 40psu and Boussiba medium at salinity 20psu. The oxidation stability was increase at salinity 40psu of both media.

Table 2. Properties of biodiesel from Nannochloropsis oculata cultured on F/2 and Boussiba media treated with different concentrations of salts, $\mathrm{P}$ and $\mathrm{N}$ starvation.

\begin{tabular}{|c|c|c|c|c|c|c|c|c|c|c|c|c|c|c|c|c|}
\hline & $\mathfrak{Q}$ & 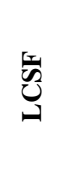 & $\frac{0}{2}$ & $\underbrace{T}$ & 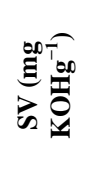 & Z & 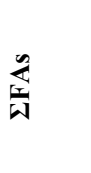 & $\sum_{\substack{0 \\
\text { W }}}^{n}$ & $\sum_{W}^{\infty}$ & 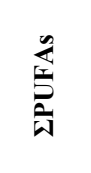 & 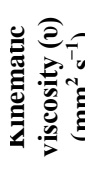 & 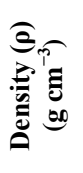 & 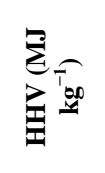 & $\stackrel{\substack{0 \\
0}}{0}$ & 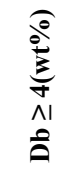 & 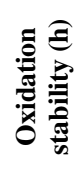 \\
\hline \multicolumn{2}{|c|}{$\begin{array}{l}\text { Biodiesel } \\
\text { Standard EN } \\
(\mathbf{1 4 2 1 4 )}\end{array}$} & & - & $\begin{array}{c}\leq 5 / \leq-2 \\
0\end{array}$ & $\leq 120$ & - & $\geq 51$ & $\geq 51$ & - & - & - & - & $3.5-5.0$ & $\begin{array}{c}0.86- \\
0.9\end{array}$ & NA & $\leq 12$ \\
\hline \multicolumn{2}{|c|}{$\begin{array}{l}\text { Biodiesel } \\
\text { Standard ASTM } \\
\text { D6751-02 }\end{array}$} & - & - & NA & NA & - & $\geq 47$ & $\geq 47$ & - & - & - & - & $1.9-6.0$ & NA & NA & - \\
\hline \multicolumn{2}{|c|}{$\min / \max$} & $\max$ & $\max$ & $\max$ & $\max$ & $\max$ & $\min$ & $\min$ & $\min$ & $\min$ & $\max$ & $\max$ & $\max$ & $\max$ & $\min$ & $\max$ \\
\hline \multicolumn{2}{|c|}{ Threshold value } & - & - & 5 & 120 & - & 47 & 47 & - & - & - & - & - & 0.9 & - & 12 \\
\hline \multicolumn{17}{|l|}{ F2 Media } \\
\hline salin 20 & 98.43 & 8.06 & 8.84 & 90.63 & 194.13 & 61.18 & 353.83 & 156.5 & 46.43 & 150.92 & 4.60 & 0.90 & 41.28 & 4.33 & 34.38 & 5.76 \\
\hline salin 40 & 44.29 & 7.28 & 6.40 & 45.73 & 202.94 & 70.91 & 131.87 & 91.18 & 22.97 & 17.72 & 4.64 & 0.94 & 42.66 & 0.90 & 2.47 & 40.52 \\
\hline salin 60 & 134.6 & 4.85 & 1.23 & 146.22 & 197.89 & 46.85 & 518.41 & 140.6 & 57.54 & 320.26 & 3.94 & 0.90 & 40.70 & 0.27 & 38.04 & 6.65 \\
\hline p starved & 58.49 & 5.61 & 1.14 & 57.82 & 204.96 & 63.83 & 656.71 & 382.5 & 164.3 & 109.92 & 4.12 & 0.89 & 40.46 & 0.10 & 11.37 & 12.87 \\
\hline N starved & 71.62 & 5.84 & 1.88 & 64.33 & 204.43 & 61.05 & 810.04 & 404.4 & 231.3 & 174.45 & 4.02 & 0.87 & 39.45 & 0.00 & 21.27 & 8.32 \\
\hline \multicolumn{17}{|l|}{$\underline{\text { BM }}$} \\
\hline salin 20 & 91.48 & 4.92 & 1.02 & 103.31 & 193.34 & 75.14 & 10.45 & 4.69 & 1.96 & 3.80 & 5.62 & 1.16 & 53.07 & 0.00 & 10.91 & 19.95 \\
\hline salin 40 & 52.58 & 4.39 & 2.67 & 61.37 & 206.67 & 71.19 & 66.00 & 44.36 & 8.58 & 13.06 & 4.58 & 1.01 & 45.92 & 0.73 & 1.76 & 50.05 \\
\hline salin 60 & 40.35 & 6.87 & 5.11 & 52.20 & 201.97 & 69.83 & 41.98 & 29.20 & 8.62 & 4.16 & 4.61 & 0.94 & 42.73 & 0.00 & 9.77 & 15.38 \\
\hline p starved & 68.96 & 5.17 & 0.25 & 76.05 & 199.35 & 71.75 & 149.35 & 84.98 & 25.75 & 38.62 & 4.94 & 1.03 & 47.00 & 4.95 & 1.11 & 23.48 \\
\hline N starved & 77.31 & 6.27 & 3.22 & 90.00 & 199.31 & 60.43 & 450.84 & 223.1 & 23.72 & 26.79 & 4.30 & 0.91 & 41.82 & 18.47 & 1.47 & 8.74 \\
\hline
\end{tabular}

\section{DISCUSSION}

Economical production of microalgae lipid in large scales is conditioned by increasing the lipid content of potential strains (Hariskos and Posten, 2014). The results obtained from the present study showed that culturing microalgae on the media 
containing salinity 60psu increased their cell numbers. This finding was consistent with the results reported by Abu-Rezq et al. (1999), they found that $N$. salina growth rate changed with different salinity concentrations. Further, they found that $N$. salina grown better upon treatment with 20 and 40ppt salinity. The lipid percentage of cell dry weight was reported as $37.7 \%$ for $N$. oculata studied earlier for biodiesel production (Ashour et al., 2019).

Changes in salinity affect the biochemical composition of microalgae (Moisander et al., 2002). The obtained data indicated the increase in protein contents of $N$. oculata with salinity stress. This result in accordance with Rai et al. (2015), they reported that protein synthesis in most microalgae cells influenced by high salinities. The present study showed an increase in the carbohydrate's contents of $N$. oculata cultured on the two different media with different salinity concentrations. This was consistent with the previous study, which reported that carbohydrate contents in microalgae increased to adapt salinity stress conditions (Mohy El Din, 2015).

Increases in salinity may produce a slight increase in total lipids in algae due to the accumulation of small molecules such as glycerol as a response to osmotic pressure (Hu et al., 2004). Botryococcus braunii growth rate was slowed by increasing salinity, but the effect on lipid concentration was minimal (Vazquez-Duhalt et al., 1991). In contrast, Rao, et al. (2007) found that there was an increase in Botryococcus braunii lipid production at higher salinity levels. El-Sheekh $\boldsymbol{e t}$ al. (2013) reported that Increase of salinity enhanced both biomass and fatty acid productivity of Scenedesmus obliquus. Also El-Sheekh et al. (2017) concluded that the increase in $\mathrm{NaCl}$ concentration up to $+100 \%$ caused an increase in growth, esterified fatty acid (EFA) content, and EFA productivity of S.obliquus.

Nutrient limitation alga are able to induce lipid production (Rodolfi et al., 2009), however, nutrient starvation led to halt in growth, and N-starvation is the effective approach to enhance lipid for biofuel production from Chlorella pyrenoidosa (Nigam et al., 2011). This study showed that culturing microalga on the media containing salinity 60psu increased the lipids production. Our results were in agreement with Hu and Gao (2005) which indicated that salts stress increased the production of lipids from microalgae. Our data agreed with the studies indicated the increase in the lipid and fatty acid compositions in $C$. vulgaris and A. obliquus strains for biodiesel production (Pandit et al., 2017). Nannochloropsis spp. can produce a high lipid content in its cells 22.7-29.7 $\%$ of the dry weight (Mata et al., 2010). The data obtained from the present study was in agreement with Ito et al. (2013); they reported that under $\mathrm{N}$ stress conditions the lipids quantities in microalgal cells were increased. The quality of biodiesel, particularly the cetane number, iodine value and saponification value were evaluated among all treatments, which commensurate, with the ignition quality, oxidative stability, and SFAs/USFAs ratio. El-Sheekh et al. (2017) showed that biodiesel from S. obliquus characterized by iodine value was high (70 g iodine/100 g oil), but viscosity, all biodiesel characteristics are in accordance with the European standards for fuel diesel (EN 590:1999).

The present study reported high cetane number and low iodine number values for biodiesel production, these findings were consistent with previous studies (Karpagam $\boldsymbol{e t}$ al., 2015; Yodsuwan et al., 2017). In general, values of CN, IV, CFPP and vi are in accordance with those recommended by International standards (2008). However, the 
high content of fatty acids with double bonds equal and/or higher than $4(\mathrm{Db} \geq 4)$ results in biodiesel oxidation instability. Comparatively, N. oceanica NIOF15/001 showed comparable high $b \geq 4$ values (Ashour et al., 2019). This is related to the high level of USFAs, especially EPA, which offers an additional advantage of dual use of $N$. oceanica for essential PUFAs extraction followed by the production of biodiesel though refining process.

\section{CONCLUSION}

In the production of biodiesel by using microalgae, having high biomass and lipid for a techno-economically sustainable system are the major obstacles, which could be overcome by manipulating medium constituents as revealed by this study. These results concluded Nannochloropsis oculata as a promising candidate for biodiesel production. It was suggested that, in respect to cost effectiveness and commercial avaliability, F/2 was preferred as a suitable medium due to its lower chemical constituents better than Boussiba medium for commercial cultivation of $N$. oculata in a large scale biodiesel production. Also recommended using higher salinities up to 40psu (available in the natural sea water) or $\mathrm{N}$-depletion and $\mathrm{P}$-depletion in $\mathrm{F} / 2$ medium that is highly economic and significantly improved biomass and lipid production of $N$. oculata than Boussiba medium. However, further studies should be encouraged for achieving the developments to implement this approach on large scale microalgae-based lipid production can be increased by salinity alteration and nutrient deprivation.

\section{REFERENCES}

Abomohra, A.; Eladel, H.; El-Esawi, M.; Wang, S.; Wang, Q.; He, Z.; Feng, Y.; Shang, H. and Hanelt, D. (2018). Effect of lipid-free microalgal biomass and waste glycerol on growth and lipid production of Scenedesmus obliquus: innovative waste recycling for extraordinary lipid production. Bioresour. Technol., 249: 992999.

Abu-Rezq, T.S.; Al-Musallam, L.; Al-Shimmari, J. and Dias, P. (1999). Optimum production conditions for different high-quality marine algae. Hydrobiol, 403: 97107.

Ashour, M.; Elshobary, M.E.; El-shenody, R.; Kamil, A.W. and Abomohra, A.E. (2019). Evaluation of a native oleaginous marine microalga Nannochloropsis oceanica for dual use in biodiesel production and aquaculture feed. Biomass Bioen., 120: 439-447.

Bligh, E.G. and Dyer, W.J. (1959). A rapid method of total lipid extraction and purification. Can. J. Biochem. Physiol., 37 (8): 911-917.

Boussiba, S.; Vonshak, A.; Cohen, Z.; Avissar, Y. and Richmond, A. (1987). Lipid and biomass production by the halotolerant microalga Nannochloropsis salina. Biomass, 12: 37-47.

Chisti, Y. (2007). Biodiesel from microalgae. Biotechnol. Adv., 25 (3): 294-306. 
Dubois, M.; Gilles, K.A.; Hamilton, J.K.; Rebers, P.A.T. and Smith, F. (1956). Colorimetric method for determination of sugars and related substances. Anal. Chem., 28 (3): 350-356.

El-Sheekh, M.; Abomohra, A.; Hanelt, D. (2013). Optimization of biomass and fatty acid productivity of Scenedesmus obliquus as a promising microalga for biodiesel production. World J. Microb. Biot., 29: 915-922.

El-Sheekh, M.; Eladel, H.M.; Abomohra, A.; Battah, M.G. and Mohamed, S.A. (2019). Optimization of biomass and fatty acid productivity of Desmodesmus intermedius as a promising microalga for biodiesel production. Energ. Source Part A., 1: 1-14.

El-Sheekh, M.; El-Gamal, A.; Bastawess, A.E. and El-Bokhomy, A. (2017). Production and characterization of biodiesel from the unicellular green alga Scenedesmus obliquus. Energ. Source Part A, 39: 1-11.

Guillard, R.R. (1975). Culture of phytoplankton for feeding marine invertebrates. In: "Culture of Marine Invertebrate Animals." Smith, W.L. \& Chanley, M.H. (Eds.). Springer, Boston, MA, pp. 29-60.

Hariskos, I. and Posten, C. (2014). Biorefnery of microalgae - opportunities and constraints for different production scenarios. Biotechnol. J., 9(6): 739-752.

Hu, H. and Gao, K. (2005). Response of Growth and Fatty Acid Compositions of Nannochloropsis sp. to Environmental Factors under Elevated $\mathrm{CO}_{2}$ Concentration. Biotechnol. Lett., 28: 987-992.

Hu, X.; Jiang, X.; Hwang, H.; Liu, S. and Guan, H. (2004). Promotive effects of algina derived oligosaccharide on maize seed germination. J. Appl. Phycol., 16: 7376.

International standards EN 14214. (2008). Automotive Fuels D Fatty Acid Methylesters (FAME) for Diesel Engines D Requirements and Test Methods. EN14214 European Committee for Standardization, UK.

Ito, T.; Tanaka, M.; Shinkawa, H.; Nakada, T.; Ano, Y.; Kurano, N.; Soga, T. and Tomita, M. (2013). Metabolic and morphological changes of an oil accumulating trebouxiophycean alga in nitrogen-deficient conditions. Metabolomics, 9 (1): 178187.

Johansen, J.R.; Barclay, W.R. and Nagle, N. (1990). Physiological variability within ten strains of Chaetoceros muelleri (Bacillariophyceae). J. Phycol., 26: 271-278.

Kamalanathan, M.; Pierangelini, M.; Shearman, L.A.; Gleadow, R. and Beardall, J. (2016). Impacts of nitrogen and phosphorus starvation on the physiology of Chlamydomonas reinhardtii. J. Appl. Phycol., 28: 1509-1520.

Karpagam, R.; Preeti, R.; Ashokkumar, B. and Varalakshmi, P. (2015). Enhancement of lipid production and fatty acid profiling in Chlamydomonas reinhardtii, CC1010 for biodiesel production. Ecotoxicol. Environ. Saf., 121: 253-257.

Kilham, S.S.; Kreeger, D.A.; Goulden, C.E. and Lynn, S.G. (1997). Effect of algal food quality on fecundity and population growth rates of Daphnia. Freshwater Biol., 38: 639-647.

Li, Y.; Lian, S.; Tong, D.; Song, R.; Yang, W.; Fan, Y. and Hu, C. (2011). One-step production of biodiesel from Nannochloropsis sp. on solid base $\mathrm{Mg}-\mathrm{Zr}$ catalyst. Appl. Energy, 88(10): 3313-3317. 
Liu, Z.; Wang, G. and Cheng, Z. (2008). Effect of Iron on Growth and Lipid Accumulation in Chlorella vulgaris. Bioreso. Technol., 99: 4717-4722.

Lowry, O.; Rosebrough, N.; Farr, A. and Randall, R. (1951). Protein measurement with the Folin phenol reagent. J. Biol. Chem., 193(1): 265-275.

Mata, T.M.; Martins, A.A. and Caetano, N.S. (2010). Microalgae for biodiesel production and other applications: A review Renew. Sust. Energ. Rev., 14(1): 217232.

Mitra, M.; Shah, F.; Bharadwaj, S.; Patidar, S. and Mishra, S. (2016). Cultivation of Nannochloropsis oceanica biomass rich in eicosapentaenoic acid utilizing wastewater as nutrient resource. Bioresour. Technol., 218: 1178-1186.

MohyEI Din, S.M. (2015). Effect of Seawater Salinity Concentrations on growth rate, pigment contents and lipid concentration in Anabaena fertilissma. CATRINA., 11(1): 59-65.

Moisander, P.H.; McClinton, E. and Paerl, H.W. (2002). Salinity effects on growth, photosynthetic parameters, and nitrogenase activity in estuarine planktonic cyanobacteria. Microb. Ecol., 43 (4): 432-442.

Nguyen, D.; Ngo, H. and Yoon, Y. (2016). Effect of internal recycling ratios on biomass parameters and simultaneous reduction of nitrogen and organic matter in a hybrid treatment system. Ecol. Eng., 89: 24-31.

Nigam, S.; Rai, M.P.; Sharma, R. (2011). Effect of nitrogen on growth and lipid content of Chlorella pyrenoidosa. Am. J. Biochem. Biotechnol., 7: 124-129.

Pan, Y.; Alam, M.; Wang, Z.; Huang, D.; Hu, K.; Chen, H. and Yuan, Z. (2017). One-step production of biodiesel from wet and unbroken microalgae biomass using deep eutectic solvent. Bioresour. Technol., 238: 157-163.

Pandit, P.R.; Fulekar, M.H. and Karuna, M.S. (2017). Effect of salinity stress on growth, lipid productivity, fatty acid composition, and biodiesel properties in Acutodesmus obliquus and Chlorella vulgaris. Environ. Sci. Poll. Res. Int., 24(15): 13437-13451.

Prince, R.C. and Kheshgi, H.S. (2005). The photobiological production of hydrogen: potential efficiency and effectiveness as a renewable fuel. Crit. Rev. Microbiol., 31(1): 19-31.

Rai, M.P.; Gautom, T. and Sharma, N. (2015). Effect of Salinity, pH, Light Intensity on Growth and Lipid Production of Microalgae for Bioenergy Application. Online J. Biol. Sci., 15(4): 260-267.

Ramirez-Verduzco, L.F.; Rodriguez-Rodriguez, J.E. and Jaramillo-Jacob, A.R. (2012). Predicting cetane number, kinematic viscosity, density and higher heating value of biodiesel from its fatty acid methyl ester composition. Fuel, 91: 102-111.

Rao, A.R.; Dayananda, C.; Sarada, R.; Shamala, T.R. and Ravishan-kar, G.A. (2007). Effect of salinity on growth of green alga Botryococcus braunii and its constituents. Bioresour. Technol., 98: 560-564.

Rawat, I.; Kuma, R.; Mutanda, T. and Bux, F. (2011). Dual role of microalgae: phycoremediation of domestic wastewater and biomass production for sustainable biofuels production. Appl. Energy, 88: 3411-3424.

Reitan, K.I.; Rainuzzo, J.R. and Olsen, Y. (1994). Effect of nutrient limitation on fatty acid and lipid content of marine microalgae. J. Phycol., 30: 972-979. 
Rodolfi, L.; Chini, Z.G.; Bassi, N.; Padovani, G.; Biondi, N.; Bonini, G. and Tredici, M. (2009). Microalgae for Oil: Strain Selection, Induction of Lipid Synthesis and Outdoor Mass Cultivation in a Low-Cost Photobioreactor. Biotech. Bioeng., 102: 100-112.

Saifuddin, M. and Boyce A.N. (2016). Biodiesel production from waste cooking sunflower oil and environmental impact analysis. Kuwait J. Sci., 43(3): 110-117.

Schenk, P.; Thomas-Hall, S.; Stephens, E.; Marx, U.; Mussgnug, J.; Posten, C.; Kruse, O. and Hankamer, B. (2008). Second Generation Biofuels: HighEfficiency Microalgae for Biodiesel Production. BioEnergy Res., 1: 20-43.

Shao, W.; Ebaid, R.; Abomohra, A. and Shahen, M. (2018). Enhancement of Spirulina biomass production and cadmium biosorption using combined static magnetic field. Bioresour. Technol., 265: 163-169.

Sibi, G.; Shetty. V. and Mokashi, K. (2016). Enhanced lipid productivity approaches in microalgae as an alternate for fossil fuels - a review. J. Energy Inst., 89(3): 330334.

Sukenik, A. and Wahnon, R. (1991). Biochemical quality of marine unicellular algae with special emphasis on lipid composition Isochrysis galbana. Aquacul., 97: 6172 .

Vazquez-Duhalt, R. and Arredondo-Vega, B.O. (1991). Haloadaptation of the green alga Botryococcus braunii (race A). Phytochemistry, 30: 2919-2925.

Vogel, A.J. (1975). A textbook of practical organic chemistry, Third ed. Longman Group Ltd., London.

Yodsuwan, N.; Sawayama, S. and Sirisansaneeyakul, S. (2017). Effect of nitrogen concentration on growth, lipid production and fatty acid profiles of the marine diatom Phaeodactylum tricornutum. Agric. Nat. Resour., 51: 190-197.

Zar, J.H. (1984). Biostatistical analysis, Second ed. Prentice-Hall, Englewood Cliffs NJ.

Zhu, L.; Li, Z.; Guo, D.; Huang, F.; Nugroho, Y. and Xia, K. (2017). Cultivation of Chlorella sp. with livestock waste compost for lipid production. Bioresour. Technol., 223: 296-300. 